\title{
FISHERIES MANAGEMENT INFLUENCE ON SOME ECOPHYSIOLOGICAL GROUPS OF BACTERIA IN LOTIC ECOSYSTEMS OF THE CEFA NATURE PARK (ROMANIA)
}

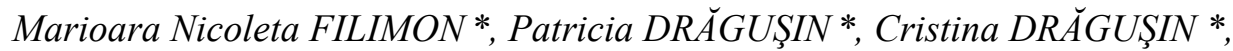 \\ Roxana POPESCU **, Maria MUGUR *, Claudia RATIS * and Sorin VOIA ***
}

\begin{abstract}
* West University, Faculty of Chemistry-Biology-Geography, Department of Biology, Timişoara, Romania, nicoleta_filimon@yahoo.com, patry_ema@yahoo.com, cristina_dragusin18@yahoo.com, mimi8929@yahoo.com, palitoknrm@yahoo.com

** University of Medicine and Pharmacy "Victor Babeş", Department of Cellular and Molecular Biology, Timișoara, Romania, popescurxn@yahoo.com

*** Banat University of Agricultural Sciences and Veterinary Medicine from Timişoara, Faculty of Animal Science and Biotehnology, Timișoara, Romania, sorin_voia@yahoo.com
\end{abstract}

KEYWORDS: lotic ecosystems, microorganisms, fishery management.

\section{ABSTRACT}

The nutrient circuit in aquatic ecosystems may seem simple, but the truth is that nutrient biochemical circuits are rather complex. Circuits are established by a series of interconnected biological, chemical and physical processes. Human activities lead to degradation of wet fields. Water quality and quantity have been changed, especially the quantity of polluting substances. Bacteriological studies in lotic ecosystems from Cefa Nature Park were carried out to establish four ecophysiologic microorganism groups: nitrogen-fixing bacteria, amonifying bacteria, nitrifying bacteria and denitrifying bacteria. Recorded values differ greatly from one species to the other according to sample points and season. Higher values in autumn are due to an increased intake of organic matter at the end of the vegetation period. Decomposition processes are intensified because of a growing number of microorganisms. Fishery management influences qualitative and quantitative variations in the microorganism communities of the lotic ecosystems in Cefa Natural Park.

RÉSUMÉ: L’influence de la gestion piscicole sur certains groupes écophysiologiques de bactéries des écosystèmes lotiques du Parc Naturel Cefa (Roumanie).

Le circuit des éléments nutritifs dans l'écosystème aquatique semble être très simple, mais en réalité, les circuits biogéochimiques nutritifs sont complexes et sont assurés par un large éventail de processus biologiques, chimiques et physiques interconnectés. Les activités humaines dégradent les milieux humides en altérant la qualité et la quantité de l'eau et en augmentant la quantité de substances polluantes. Les études bactériologiques réalisées dans les écosystèmes lotiques du Parc Naturel Cefa ont été considérées pour déterminer les quatre groupes de microorganismes écophysiologiques suivant: les bactéries fixatrices d'azote, les bactéries ammonifixatrices, les bactéries nitrifiantes et les bactéries de dénitrification. Les valeurs enregistrées par groupes de bactéries écophysiologiques analysées sont très différentes d'un sexe à l'autre en fonction du point d'échantillonnage et selon la saison. Les valeurs plus élevées de l'automne dans les points d'échantillonnages sont déterminées par la contribution accrue de la matière organique à la fin de la saison de croissance, indiquant un processus de décomposition accrue sous l'action d'un grand nombre de microorganismes. La gestion piscicole influence dans une moindre mesure les variations quantitatives et qualitatives des communautés de microorganismes provenant d'écosystèmes lotiques du Parc Naturel Cefa. 
REZUMAT: Influenţa managementului piscicol asupra unor grupe ecofiziologice de bacterii din ecosistemele lotice din Parcul Natural Cefa (România).

Circuitul nutrienților în ecosistemele acvatice pare simplu, însă în realitate, circuitele biogeochimice ale nutrienţilor sunt foarte complexe, fiind realizate printr-o gamă largă de procese biologice, chimice şi fizice interconectate. Activităţile umane determină degradarea zonelor umede prin modificarea calitativă şi cantitativă a apei, în special prin creşterea cantităţii substanţelor cu efect poluant. Studiile bacteriologice realizate în ecosistemele lotice ale Parcului Natural Cefa au avut în vedere determinarea a patru grupe ecofiziologice de microorganisme: bacterii fixatoare de azot, bacterii amonificatoare, bacterii nitrificatoare şi bacterii denitrificatoare. Valorile înregistrate în ceea ce priveşte grupele ecofiziologice de bacterii analizate diferă foarte mult de la un gen la altul, atât în funcţie de punctul de prelevare a probei, cât şi în funcţie de sezon. Valorile ridicate din sezonul de toamnă la nivelul punctelor de prelevare sunt determinate de aportul crescut de materie organică de la sfârşitul perioadei de vegetaţie, ceea ce indică intensificarea proceselor de descompunere sub acţiunea unui număr mare de microorganisme. Managementul piscicol influenţează într-o mică măsură variaţiile calitative şi cantitative ale comunităţilor de microorganisme din ecosistemele lotice ale Parcului Natural Cefa.

\section{INTRODUCTION}

Soggy fields have natural filters playing a significant part in bringing about the results of an improved water quality. This is due to a surface overflow, mostly coming from urban systems and agricultural land in order to decrease pollution. It is well known that soggy fields and other ecological ecosystems have a certain kind of support: the ability to assimilate nutrients. Nutrient over retention leads to structure alteration in soggy fields. Also, nutrients are kept in separate divisions: plant tissues, microorganism biomass, detritus, sediment and water (Mihăescu, 2000).

There are three procedures for the nutrients to be immobilized or recycled in soggy fields: plant and microorganism absorption, sedimentation, denitrifying, ammonium and molecular nitrogen volatilization. Nitrogen discharge from the ecosystem into the atmosphere has been made in form of molecular nitrogen $\left(\mathrm{N}_{2}\right)$. In the first two procedures, nutrients are immobilized and retained in the soggy fields (Denovan et al., 2000).

Nitrogen compounds retained in the soggy field depend on vegetation, season and their ability to survive. It has been established that, as long as the nutrient input grows, their retention grade decreases. Nutrient concentration from the soggy fields has a negative effect on the ecological system. Tsushima et al. (2002) identified possible causes for floods during the nitrogen's biochemical cycle. They also recorded species in the aquatic dynamics, the inorganic nitrogen from river Tama.

Several researches have been interested in which is the appropriate concentration of nitrogen in order to protect the systems. Based on certain studies, it has been established that the nitrate concentration $\left(\mathrm{NO}_{3}^{-}\right)$higher than $2 \mathrm{mg} / \mathrm{l}$ or the total nitrate concentration higher than $1.35 \mathrm{mg} / \mathrm{l}$ interfere with plant development. In spring, we have a higher concentration of nutrients which put in danger the macrophyte development. It is important for us to mention that limit concentrations vary a lot from one region to the other. Concentrations depend on multiple facts according to every region.

Two of the most important factors are: the soggy field type (swamps, pools and riparian areas) and the vegetation type (as we have previously mentioned). Nutrient circuit in aquatic ecosystems may seem to be easy, but the truth is that nutrient biochemical circuits are rather complex. Circuits have been established with the help of many biological, 
chemical and physical procedures, connected among them. Each process influences another type of process. Human activities determined soggy field degradation because of changes in water quality and quantity, in the hydrological balance and in the growing number of pollutants. Species are changed by size because of the damage that has been caused (UCMP, 2004).

Ecophysiologic bacteria groups from the biochemical circuits are of a great importance and are even more studied lately. Thus, bacterial communities implied in nitrogen recycling (heterotrophic, denitrifying, nitrifying, proteolytic bacteria) have been determined in the aquatic divisions from river Olt (Astratinei, 2000).

Microbiological studies of sediment from a polluted area like river Mureş pointed out ecophysiologic groups of bacteria during the nitrogen cycle: heterotrophic, aerobic, desulfying and iron-reducing bacteria (Ştef et al., 2004). Identifying pollution sources and their effects on the ecophysiologic microorganism group from water and river sediment from Timiş River has enabled us to identify pollution coming from nearby livestock farms. The number of microorganisms has been reduced as well as the nitrogen fixing microorganism activity from the aquatic sediment (Filimon et al., 2009). Nitrogen fixing aerobe bacteria (Azothobacter chroococcum and Azothobacter vinellandi) and nitrogen fixing anaerobic bacteria from the Clostridium sp. recorded numerical variations in sediments from Timiş and Bega rivers (Filimon et al., 2010).

The aim of this work has been to identify the influence of fishery management on microorganism communities from Cefa Nature Park`s aquatic ecosystems, based on ecophysical bacteria groups implied in nitrogen`s biochemical circuit.

\section{MATERIAL AND METHODS}

Bacteriological studies

Nitrogen fixing bacteria was emphasized using the Ashby method, with the following chemical composition: $\mathrm{K}_{2} \mathrm{HPO}_{4}$ 0,5 g, NaCl 0,5 g, $\mathrm{MgSO}_{4} 0,2 \mathrm{~g}, \mathrm{~K}_{2} \mathrm{SO}_{4} 0,1 \mathrm{~g}, \mathrm{CaCO}_{3} 5 \mathrm{~g}, 5 \mathrm{~g}$ of commercial sugar, $1000 \mathrm{ml}$ distilled water. Samples are incubated for a week at $27^{\circ} \mathrm{C}$, then for each sample and dilution, the number of positive tubes are read. For the aerobic fixing of nitrogen, the appearance of a mantle on the surface is considered positive or at least, the appearance of a ring on the tube walls. Often the color of this mantle is fluorescent yellowishgreen (characteristic of $A$. vinellandii). Most often the color is brown (typical for $A$. chroococcum). For anaerobic fixing (the Clostridium sp.) a positive feature is the appearance of gas bubbles (Dunca et al., 2004).

Numerical determination of ammonifying bacteria was realized using the culture medium with peptone, which has the following chemical composition: $\mathrm{NaCl} 0.5 \mathrm{~g}$, peptone 2 $\mathrm{g}$, distilled water $1000 \mathrm{ml}$. The incubation was carried out at $22^{\circ} \mathrm{C}$ for 14 days. Highlighting ammonia produced by the ammonifying bacteria activity is made by a specific color reaction with Nessler reagent. Intense yellow coloration is obtained with or without precipitation (Cuşa, 1996).

For the growth of nitrifying bacteria, the Barjac culture medium with the following chemical composition is used: $\mathrm{KNO}_{3} 2 \mathrm{~g}$, glucose $10 \mathrm{~g}, \mathrm{CaCO}_{3} 5 \mathrm{~g}$, Sol. Vinogradski $50 \mathrm{ml}$, distilled water $950 \mathrm{ml}$. The nitrate freed following the nitrifying bacteria's activity can be evidenced through a blue colour reaction with diphenylamine-sulfuric acid reactant (DrăganBularda, 2000). 
To highlight the denitrifying process dilutions of sediment are seeded in a liquid medium where the nitrogen is present as nitrate. The culture medium has the following composition: standard saline solution $50 \mathrm{ml}, \mathrm{KNO}_{3} 20 \mathrm{~g}, \mathrm{C}_{6} \mathrm{H}_{12} \mathrm{O}_{6} 10 \mathrm{~g}, \mathrm{CaCO}_{3} 5 \mathrm{~g}$, oligoelemental solution $1 \mathrm{ml}$, distilled water until $1000 \mathrm{ml}$. The incubation is carried out at $28^{\circ} \mathrm{C}$ for 7-15 days after which diphenylamine-sulfuric acid is added in the tubes. A blue coloration appears (negative reaction) in the tubes where nitrate remained. The eprubetes where nitrates disappeared are colourless (positive reaction) (Dunca et al., 2007).

According to the ecophysiologic bacteria group, the bacterial indicator of soil quality (BISQ) has been established, based on a formula proposed by Muntean (1995-1996, 1996): $\mathrm{BISQ}=1 / \mathrm{n} \times \Sigma \log 10 \mathrm{~N}$, where: BISQ - bacterial indicator of soil quality, $\mathrm{n}$ - number of ecophysiologic groups, $\mathrm{N}$ - number of bacteria appertaining which belongs to each ecophysiologic group.

Sample point description

Sample points have been chosen from Cefa Nature Park, a lotic aquatic habitat. Three stations have been established:

Station 1: collecting channel (Criş in local toponymy). Stronger water flow, in northwest, the channel is a link between Crişul Repede and Crişul Negru rivers. Water depth: 2-3.5 $\mathrm{m}$, gritty sediment, macrophyte algae fields, silt deposits and detritus, loamy banks with swamp vegetation (Typha sp., Phragmites sp.).

Station 2: Ateaş evacuation channel - depth $1.5 \mathrm{~m}$, width 3-4 m. Sandy and loamy surface, weak submerged vegetation.

Station 3: Lake 14 feed channel - riverbed width 4-5 m. Maximum depth $2 \mathrm{~m}$, loamy surface, silt deposits and detritus.

\section{RESULTS AND DISCUSSIONS}

Bacteriological studies had in view to establish four types of ecophysiological microorganism groups: nitrifying, amonifying, denitrifying and nitrate fixing bacteria. As concerning studied ecophysiologic bacteria groups, the recorded values are rather different from one species to the other. The highest values have been recorded for the amonifying bacteria $\left(10^{5}-10^{6}\right)$, followed by the nitrifying, denitrifying bacteria, Azothobacter vinellandi aerobic nitrate fixing bacteria and Clostridium sp. anaerobic nitrate fixing bacteria $\left(10^{3}-10^{4}\right)$.

Lower values have been recorded for the Azothobacter chroococcum species, aerobic nitrate fixing bacteria $\left(10^{3}\right)$. Nitrate fixing bacteria form two separate groups: Azothobacter vinellandi and Azothobacter chroococcum, aerobic nitrate fixing bacteria and Clostridium sp. anaerobic nitrate fixing bacteria. Anaerobic and aerobic nitrate fixing bacteria have been found in every sample point. Nitrate fixing bacteria in sediment from the lotic ecosystem found in Cefa Nature Park reveal nitrate organic and inorganic compounds. Nitrate fixing bacteria have a higher content of $\mathrm{N}_{2}$ taken in from the atmosphere.

A higher value of nitrates increases vegetal mass and it also improves other nitrate procedures. Aerobic nitrate fixing bacteria like the Azothobacter vinellandi are much better represented numerically as compared to Azothobacter chroococcum and Clostridium sp.

In summer and autumn a higher number of Azothobacter vinellandi, aerobic nitrate fixing bacteria is in accordance with vegetal mass development. In spring, we established a higher number of Clostridium sp., anaerobic nitrate fixing bacteria. The aquatic ecosystem has nitrate compounds in it. Clostridium sp. species enable molecular nitrates to reach into the sediment. This is beneficial for the productivity and for the nitrate circuit. Three nitrate fixing bacteria groups have the same values as in spring, meaning an efficient nitrate circuit in the studied aquatic system (Fig. 1). 
Maximum values in summer and autumn for nitrate fixing bacteria in sample point II are determined according to a higher concentration of molecular nitrates. Higher concentration of molecular nitrates is recorded due to decomposing organic substances (Fig. 2).

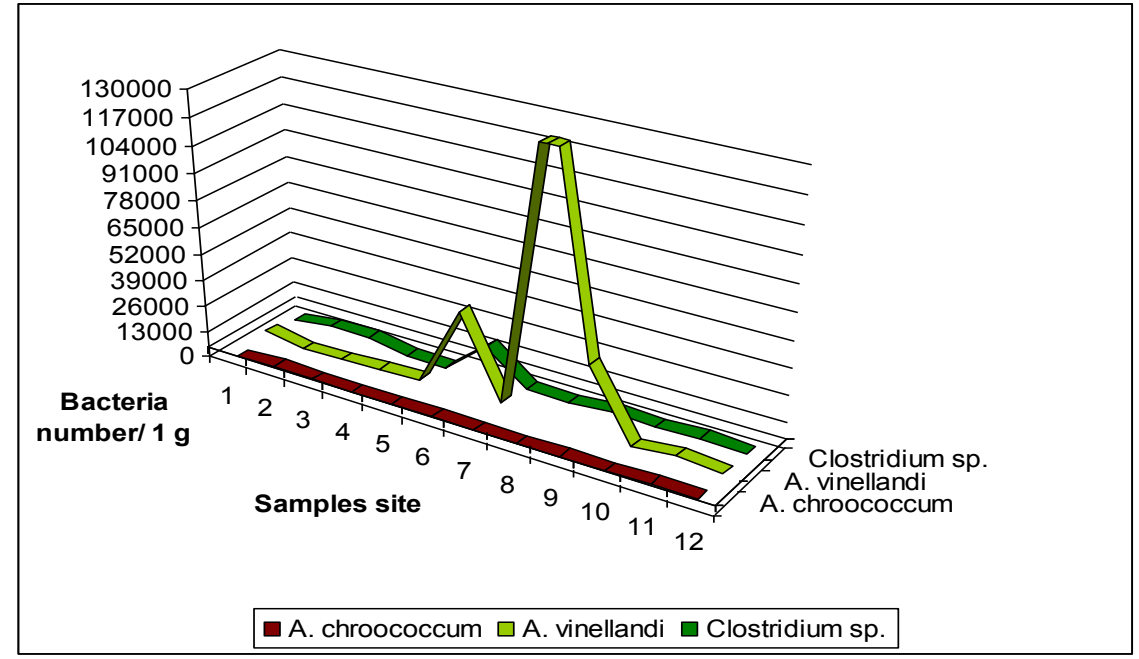

Figure 1: Nitrogen fixing bacteria in studied samples.

Higher values of the amonifying bacteria in summer, at each sample point, reveal that the nitrogen compound improves the development of the amonifying bacteria and, implicitly, the ammonia concentration. Vegetation influences the sediment rate of nutrient particles, the vegetation overtake and the nutrient release in autumn and winter. Plant biomass and seasonal conditions influence the quantities of organic substance and also the carbon and oxygen from the sediment. Organic substances and carbon from sediment have to undergo series of procedures like overtaking, transforming, denitrifying and other chemical and physical procedures in sediment and at the interface between water and sediment (Fisher et al., 2009).

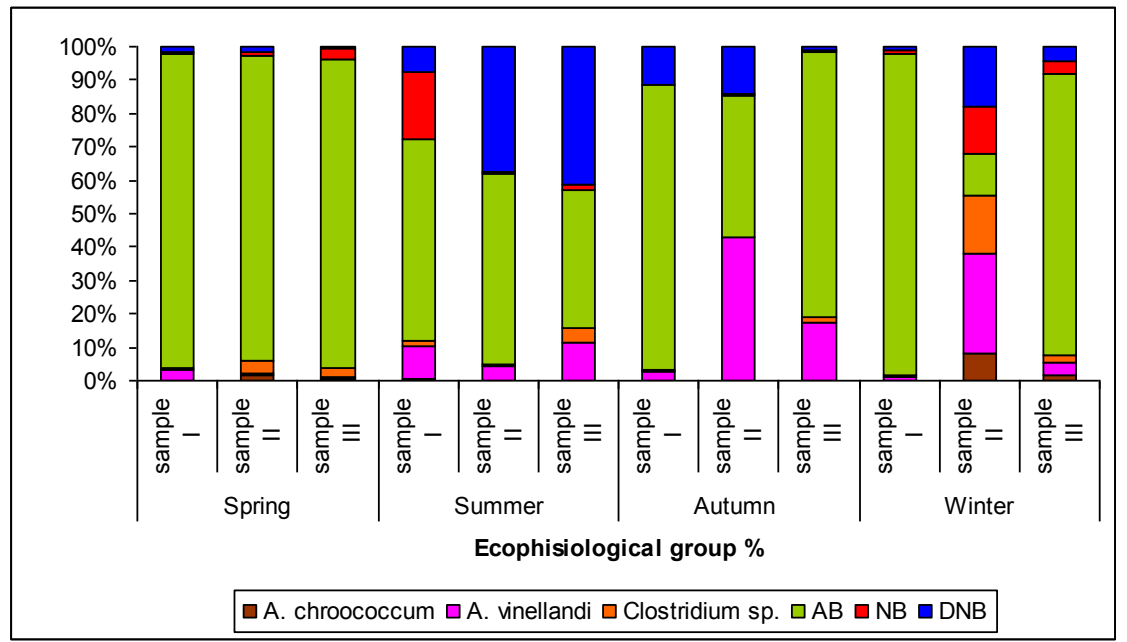

Figure 2: Bacteria division during the nitrogen circuit $(\mathrm{AB}$ - amonifying bacteria, NB - nitrifying bacteria, DNB - denitrifying bacteria). 
In soggy fields, ammonium decreases and nitrate increases. This is the result of an incomplete denitrification. A complete oxidation requires ammonium oxidation in the nitrates. Nitrates are later transformed in molecular nitrogen. This is the reason why the first procedure is developing faster, when compared to the second one (Camargo and Alonso, 2007).

The existence of anaerobic conditions or the organic carbon's availability (forming a donor electron) has a vital importance in nitrate reduction. As water and the interface between water and sediment are oxygenated, the complete denitrifying procedure shall be limited. These conditions establish nitrate reduction, increasing denitrifying bacteria, donor electrons and the nitrate substrate. It is important to mention the link between aerobic and anaerobic conditions. Due to the fact that the anaerobic ones are predominant, micro-organism diversity and denitrifying efficiency may be reduced.

In this case, we should take into consideration the depth and flood rate. The nutrient resistance has been reduced (three hours) and is directly related to nutrient recycling due to the difference between water and sediment, bacteria or plants (LPELC, 2009).

Nitrifying bacteria are spreading quickly, but are few in number when compared to the other two groups. Nitrates are less toxic for creatures living in aquatic sediments. For plants, it is even beneficial. Nitrates are the ultimate link in a nitrogen change. Nitrates gather together in time. For biocenosis, nitrites' and nitrates' toxicity acts differently according to species, age and exposure period.

Denitrifying bacteria are well represented in summer and autumn. It reveals nitrite and nitrate decomposure in water and sediment. There is an inverse proportionality between denitrifying and nitrifying bacteria (Fig. 3).

Denitrifying capacity depends on vegetation type. As denitrifying capacity increases, certain submerged species produce a high quality organic substance. It is a support for heterotrophic bacteria. Vegetation offers more space to bacteria, bringing into existence many new populations.

It has been proved that the nutrient recycle has a higher rate when there are plants nearby. Plants may also inhibit denitrifying processes through the oxygen loss. The effect depends on species, development and on plant biomass. Plants fill bacteria with carbon. Denitrifying processes become carbon and an energy source. Recycling rate is higher when there are different kinds of species (Bastviken et al., 2005).

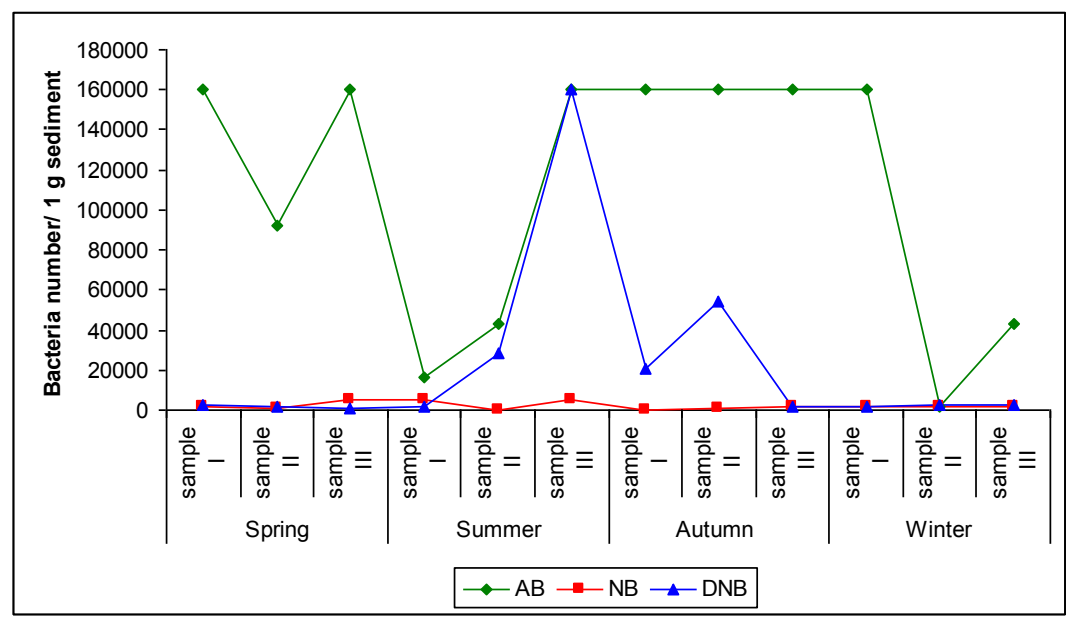

Figure 3: Ecophysiologic bacteria groups $(\mathrm{AB}$ - amonifying bacteria, $\mathrm{NB}$ - nitrifying and DNB - denitrifying bacteria) in sample points from lotic ecosystems in Cefa Nature Park. 
Sample point number III has higher values in every studied ecophysiological group due to sediment consistency with mud deposits and detritus.

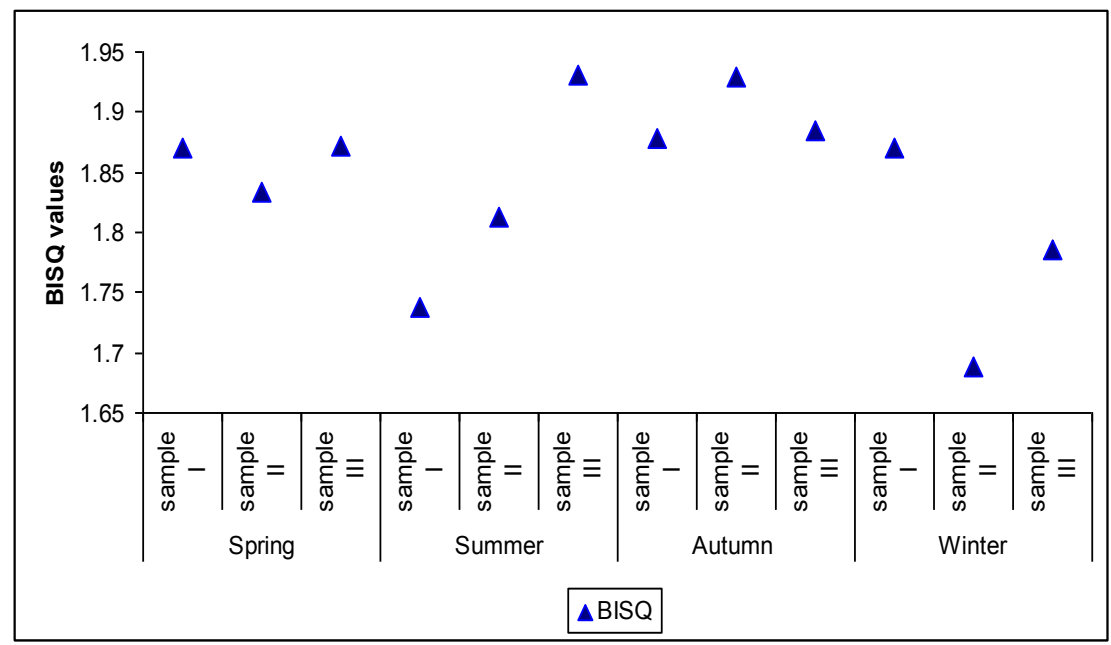

Figure 4: Bacterial indicator of sediment quality in sample point taken from lotic ecosystems in Cefa Nature Park.

Based on absolute values from every microorganism group, the bacterial indicator of sediment quality has been established (BISQ). BISQ offers an overview about the decomposing process in the studied aquatic ecosystem. Pollution sources and their influence on microorganisms have been identified. The bacterial indicator of sediment quality has values between 0.93 at the level of L14 feed channel in summer and 0.69 at the level of Ateas evacuation channel in winter (Fig. 4). Bacterial indicator of sediment quality from the lotic ecosystem varies according to every sample point and every season. Higher values are recorded in summer and autumn. Lower values are recorded in spring and winter. Higher values are probably due to a favourable temperature. In summer, water temperature is higher. In winter, the water is frozen. Higher values in autumn are determined by a large amount of organic substance at the end of the vegetation period. Organic substances are decomposing intensively.

\section{CONCLUSIONS}

Ecophysiologic bacteria groups implied in the nitrogen cycle from the lotic ecosystem of Cefa Nature Park record quantitative values according to every sample point and every season.

Higher values in autumn in 3 sample points have been established by a large amount of organic matter at the end of the vegetation period. Decomposing procedures are intensified, the number of microorganism is higher.

Fishery management influences in a certain way the qualitative and quantitative variations of microorganism communities from lotic ecosystem of Cefa Nature Park. 


\section{REFERENCES}

1. Astratinei V., 2000 - Associations of bacteria involved in matter recirculation in continental aquatic ecosystems, Studii şi Cercetări Ştiinţifice, Seria Biologie, Bacău, 5, 157-164.

2. Bastviken S. K., Eriksson P. G., Premrov A. and Tonderski K., 2005 - Potential denitrification in wetland sediments with different plant species detritus, Ecological Engineering, 25, 183-190.

3. Camargo A. J. and Alonso A., 2007 - Inorganic nitrogen pollution in aquatic ecosystems: causes and consequences, The Encyclopedia of Earth, Environmental chemistry, Ecology, Marine ecology, 12.

4. Cusa V., 1996 - Instrucțiuni metodologice pentru analiza microbiologică a sedimentelor din ecosistemele acvatice, (in Romanian), Institutul de Cercetări în Ingineria Mediului, București, 4: 14-20.

5. Denovan D. and Wotze C., 2000 - Wetlands and water quality entrancement, School of Applied Environmental Sciences, University of Natal.

6. Drăgan-Bularda M., 2000 - Lucrări practice de microbiologie generală, Univ. „Babeș-Bolyai”, Cluj-Napoca. (in Romanian)

7. Dunca S., Ailiesei O., Nimitan E. and Ştefan M., 2004 - Microbiologie aplicată, Editura Demiurg, Iaşi. (in Romanian)

8. Filimon M. N., Gotia S. R., Gotia S. L., Borozan A., Popescu R. and Gherman V. D., 2009 Bacteriological studies on River Timiş with a role in evaluating pollution, Annals of RSCB, XIV, 2, 284-288.

9. Filimon M. N., Borozan A., Sinitean A., Popescu R., Török-Oance R. and Verdeș D., 2010 Bacteriological studies on Timiş and Bega Rivers with a role in apreciating pollution, Annals of the Romanian Society for Cell Biology, XV, 2, 217-220.

10. Fisher J., Stratford C. J. and Buckton S., 2009 - Variation in nutrient removal in three wetland blocks in relation to vegetation composition, inflow nutrient concentration and hydraulic loading, Ecological Engineering, 35, 1387-1394.

11. Mihăescu G., 2000 - Microbiologie generală şi virusoligie, Edit. Universităţii Bucureşti. (in Romanian)

12. Muntean V., 1995-1996 - Bacterial indicator of mud quality, Institutul de Cercetări Biologice, Contribuții Botanice, 73-76.

13. Ştef L. C., Muntean V. and Drăgan-Bularda M, 2004 - Microbiological research on the Mureş sediments from Ocna Mureş affected by pollution, Contribuţii Botanice, XXXIX, 227-232.

14. Tsushima K., Ueda S. and Ogura N., 2002 - Nitrate loss for denitrification during high frequency research in floodplain groundwater of the Tama River, Journal of Water, Air and Soil Pollution, 137(1-4), 167-178.

15. http://UCMP, 2004.

16. http://twitter.com/LPELC, 2009. 